\title{
Between Cosmopolitism and Westphalia: the case of terrorism
}

\author{
Laura PLANAS GIFRA*
}

\begin{abstract}
The construction of global norms has always been complex, but today this has become more evident than before. The willingness to create an international legal framework might be less seductive than before. What is more, in the field of security it becomes even harder to develop global norms, as security is intrinsically linked with the sovereignty of the state, which might lead to more unwillingness to be bound by international obligations. States share different approaches on how to solve international problems, which complicates the designing a common international strategy. Some share a perspective based on Cosmopolitism which involves international cooperation, while others base their security strategies on geopolitical concerns and national interests. The case of terrorism is of particular importance as in the past couple decades it has become one of the most serious threats to international peace and security. And while this should be reason enough to agree on finding a common solution, its sole definition has become a complex matter. This paper analyses the necessity of developing global norms on terrorism and the difficulties of their approval precisely because of the clash between models based on Cosmopolitism and those based on Westphalia.
\end{abstract}

Keywords: international norms, terrorism, Cosmopolitism, Westphalia

\section{(A) INTRODUCTION}

While the international order used to be structured around power balances and geopolitics, after the end of the Cold War it seemed as if the Westphalian system was beginning to weaken to make room to a new model based on Cosmopolitism, with liberal values emerging and spreading throughout. However, what recent events have shown us is that geopolitical conceptions have remained and still own an important place in the way in which some states base their national security strategies. These views are finding a more influential place and frontally clashing with Cosmopolitism.

The dominance of geopolitical powers has always been clearer in the field of security, where sovereignty has always been put at the forefront of what states wanted to preserve the most. However, when it comes to terrorism, an international phenomenon which is now affecting not just a few, but most nations in the world, there is a clear need to find common grounds to coordinate efforts and fight through a joint strategy. We have, from the one hand, the preservation of national security interests and powers, and from the other, the need to cooperate to solve a problem which cannot be solved only through unilateralism.

On top of that, while there was a period of international law-making and a certain preference towards adopting hard-law instruments, more recently we have seen an unwillingness by states to give up part of their sovereignty to be bound by certain international obligations. The result is that it is now more difficult to develop international instruments, such as the case for a Comprehensive Convention on International Terrorism, which would provide a definition of international terrorism for all. We see some states pushing for the negotiation of the text, and others being reluctant to adopting international norms compromising themselves in the field of security. This conflict between these two approaches and the difficulties on adopting an international norm on terrorism to combat

\footnotetext{
* Doctoral candidate in Law at Pompeu Fabra University. Email: laura.planas@upf.edu.
} 
such a dreadful phenomenon may be useful to show the existing clash between Cosmopolitism and Westphalia. This is what this paper will try to analyse.

\section{(B) THE CONSTRUCTION OF GLOBAL NORMS IN TODAY'S INTERNATIONAL ORDER}

In recent scholarly debates, some have referred to the change of powers in the current international order, or even to the emergence of a completely new one. The relationship between states and the way they interact with each other has changed during the past decades. This has partly been due to globalization, the emergence of new international actors, new emerging powers, and different economic relations. While international public law still governs these interconnections, because of this new organizational functioning, the way in which norms emerge has changed.

In the modern era, international order was built based on the Westphalian system, which meant the balancing of powers, geopolitical strategies, and the prevalence of territorial sovereignty. After the Second World War, new principles based on the promotion of social, economic, and cultural development began taking the stage, and along with the United Nations, a more global order based on Cosmopolitism values was established. ${ }^{1}$ However, in recent years we have witnessed the rise of China, which along with Russia are challenging the liberal values established by the West. Instead, they want to reinstall sovereignty and territorial integrity as the basis for international relations. ${ }^{2}$ Furthermore, during the Trump administration, the United States also returned to unilateralism. And more recently, we have also seen the intensification of conflicts like those affecting the South China Sea, the Arctic, and the increasing instability of those countries in the Middle East.

With all these power shifts and new power balances, along with the intensification of global problems such as those related to climate change, migration, nuclear energy, and so on, the world is facing some important challenges. In this context, some scholars have focused on the changes in the nature of international law to analyse whether international norms emerge in different forms today. ${ }^{3}$ There is, in some way, a tendency to return to the Westphalian model. That is, states are more often less keen to bind themselves by international norms and to sign new international treaties which will then involve new obligations. And when it comes to security issues, states are even more unwilling to develop more international norms. Although this is not a "return" to the Westphalian model per se, the question is whether we ever left it at all. The impact of Cosmopolitism on security affairs might not have been so strong after all.

Furthermore, non-state actors such as civil society and private enterprises have a much relevant role today and participate in regulatory activities. Their part during negotiations and drafting norms is now more evident than ever. Globalization, privatization, and the fragmentation of states has

B. Buzan and G. Lawson, The Global Transformation: History, Modernity and the Making of International Relations (Cambridge University Press, Cambridge, 2015).

2 M. Mazarr, M. Priebe, A. Radin, and A. Stuth Cevallos, 'Understanding the Current International Order', RAND Corporation (2016), at 11.

N. Deitelhoff and L. Zimmermann, 'Norms under challenge: Unpacking the Dynamics of Norm Robustness', 4(1) Journal of Global Security Studies (2019) 2-17, [doi: https://doi.org/10.1093/jogss/ogy041]; A. Wiener, The Invisible Constitution of Politics: Contested Norms and International Encounters (Cambridge University Press, New York, 2008), [doi: https://doi.org/10.1017/CBO9780511490408]; L. Zimmermann, 'More for Less: The Interactive Translation of Global Norms in Postconflict Guatemala', 61(4) International Studies Review (2017) 774-785, [doi: https://doi.org/10.1093/isq/sqx044]. 
introduced these new actors into the game field ${ }^{4}$ which, along with technological advancements in relation to information, computing and communication services has facilitated their involvement and their level of influence. Inter-governmental organizations contribute to solving international conflicts operating by the consent of the states, but they also count with experts who work to analyse international disputes and give their expertise to solving them. Non-governmental organizations many times lobby to influence both international organizations and governments to defend human rights, while also monitoring and bringing to justice those who do not comply with the law. And even more interesting is the role of transnational or multinational corporations which have become more powerful over time and are also key in determining the outcome of those norms affecting their spheres of influence.

This growing role and impact of non-state actors is explained precisely by the changes in the global order. The international system is no longer made only of states, but it is instead a pluralistic society made of different types of actors who participate with more or less success in influencing the norm making process. Trade unions, corporate businesses, religious groups, academics, think-tanks, etc. They are all involved in legislative and decision-making operations. The role of the state is still crucial, but the state is no longer alone, and more hybrid governance frameworks where the interaction between state and non-state actors is seen more frequently than before.

It seems that we are moving towards an even more pluralistic system, one with new actors, new emerging powers, and new power shifts. The reality of the international order has changed, and the debate on whether we are witnessing a return to the Westphalian system that used to be in place during the $19^{\text {th }}$ and $20^{\text {th }}$ centuries is more evident today. Within this framework, one may wonder whether international norms to solve global problems should be emerging more easily today or whether they face too many difficulties. It seems that even though there is a greater number of actors participating in the norm creation process, the fact that common problems need of an international agreed response might lead to greater cooperation processes. While this is obvious in areas such as climate change and the protection of the environment, nuclearization or migration movements among others, in other sectors states may not be so willing to oblige themselves under certain international obligations. This is what this paper will seek to explain in the following lines and in relation to terrorism in particular.

\section{(C) GLOBAL NORMS IN THE CONTEXT OF THE WAR ON TERROR}

The last couple decades we have witnessed multiple terrorist attacks in different parts of the world by international terrorist groups. The terrorist threat is now one of the main concerns of many nations, and we have seen how national security strategies now include the fight against terrorism as one of their main priorities. On a larger scope, it has also been recognized that terrorism is a major threat to international peace and security.

This has meant that terrorist legislation has expanded both at the domestic and international levels. This "rush to law" is explained by the need which some states have felt to respond to this security threat through the legislative. Terrorism-related norms are not a phenomenon of the $21^{\text {st }}$ Century, as

\footnotetext{
4 K. Creutz, T, Iso-Markku, K. Raik and T. Tiilikainen, 'The changing global order and its implications for the EU', 59 Finnish Institute of International Affairs (2019), at 37.

5 J. C. Barker, 'The politics of international law-making: Constructing security in response to global terrorism', 3(1), Journal of International Law and International Relations (2007) 5-30, at 5.
} 
the first treaties in the field were the Convention on Offences and Certain Other Acts Committed on Board aircraft of 1963 (commonly known as the Tokyo Convention), the Convention for the Suppression of Unlawful Seizure of Aircraft of 1970, and the Convention for the Suppression of Unlawful Acts against the Safety of Civil Aviation of 1973 (commonly known as the Montreal Convention). Regionally, other treaties were approved from the 70s and well through the 90s. And before $9 / 11$, terrorist attacks were already considered to be threats to international peace and security by the Security Council after the Kenya and Tanzania attacks of 1998. ${ }^{6}$ However, September 11 was a crucial moment because it has been since then that most of the legal development in the field has advanced.

The international community has been able to establish some landmarks through the Security Council on the war against terrorism, and these came as a response after the September 11 attacks. Resolution 1373 of $2001^{7}$ and Resolution 1566 of $2004^{8}$ became an important normative basis for the Security Council, since these resolutions invoked Chapter VII of the United Nations Charter requiring states to take certain national legislative measures. Shortly after 9/11, the first of these resolutions was adopted, and it invoked all states to take active measures against the terrorist threat. States were demanded to categorise terrorism as a crime and to cooperate between nations to prevent such attacks from happening. It was the first time the Security Council compelled states to change their national laws to include anti-terrorist legislation and the first time it declared terrorism as a threat to international peace and security. Later, this position was reinforced through Resolution 1566, as it went even one step further and stated that "terrorism in all its forms and manifestations constitutes one of the most serious threats to peace and security." The Resolution also included certain terminology associated with terrorism that would later on guide state practice in the field. And even though there is a provisional definition of terrorism, because of its non-compulsory nature, it has not been enough to lead to a uniform legal definition of the crime. ${ }^{9}$

Shortly after, new measures were adopted to combat this phenomenon, such as the establishment of the Security Council Counter-Terrorism Committee in 2001, of the Counter-Terrorism Committee Executive Directorate, and the approval of a common plan to respond to the terrorist threat agreed through the adoption of the UN Global Counter-Terrorism Strategy in September 2006. ${ }^{10}$ However, Resolution 1373 has remained as one of the core instruments on international terrorism because, even though there can be a discussion on whether the Security Council does have or not legislative powers by virtue of the Charter, the resolution was extensively supported. The consideration of terrorism as a common international threat and the interest on combatting it seems to be obvious, and even if to date there are 19 international United Nations treaties in the field of terrorism, a definition on the international crime of terrorism is still missing.

But such a definition is crucial for various reasons. First, the lack of a common international definition leaves the door open for states to develop their own definitions at the domestic level, which leads to great discrepancies from one another, but can also lead to the violation of certain human rights -accidentally or willingly. As stated in Article 15 of the International Covenant for Civil and

SC Res. 1269 (1999), 19 October 1999

SC Res. 1373 (2001), 28 September 2001

SC Res. 1566 (2004), 8 October 2004

9 B. Saul, 'Legislating from a Radical Hague: The United Nations Special Tribunal for Lebanon Invents an International Crime of Transnational Terrorism', 24(3) Leiden Journal of International Law (2011) 677-700, at 685 [doi: https://doi.org/10.1017/S0922156511000203].

10 GA Res. 60/288 (LX), 20 September 2006 
Political Rights in respect of the principle of legality, all dispositions should be clear and precise enough to respect the principle of legal certainty. It is also important to distinguish terrorism from other forms of armed conflict which certain states may infringe under their domestic legislation as to supress the rights of activists and civil society organizations in their countries. Thus the lack of a formal definition of the crime of terrorism weakens the main goal of establishing such a definition, which is to regulate and combat the terrorist threat by protecting the security of all.

When it comes to the establishment of global norms it is usually much harder to find agreement since there is a multiplicity of interests involved, an obstacle that becomes even more evident in the field of defence. Each nation has its own interests and goals, but they also have different approaches regarding how to solve international problems. Some may have a more "cosmopolitist" view through which international cooperation and agreement are the basis of their international relations, while others may prioritize geopolitical perspectives. Moreover, security is intrinsically linked to sovereignty, which makes this area more even more complex for finding common agreement.

In the fifty-ninth session of the General Assembly, the Secretary General stated that "Today, more than ever before, threats are interrelated and a threat to one is a threat to all. The mutual vulnerability of weak and strong has never been clearer. Global economic integration means that a major terrorist attack anywhere in the developed world would have devastating consequences for the well-being of millions of people in the developing world." ${ }^{11}$ However, while different measures have been approved by the United Nations and states altogether to protect from the terrorist threat, states are less enthusiastic to continue approving international norms and prefer following their own strategies according to their national security interests.

\section{(D)}

TERRORIST LAWS AT THE REGIONAL LEVEL

Up until 11 September 2001, most of the efforts by the international community to combat terrorism were directed towards coordinating measures to supress international terrorist organizations. Nevertheless, after the 11 September attacks, most governments started increasing their measures to combat this phenomenon through laws and policies which would prioritize their own national security, even though these measures would sometimes harm the rights of their citizens. The security of the state was above all, which at times even led to human rights violations.

At the regional level we see different tendencies in these regards. While some regions are more directed towards cooperation and harmonization, others believe in the greater efficacy of unilateral actions. In the Inter-American region, the Inter-American Convention Against Terrorism of 2002, states declared that "strengthening hemispheric cooperation to prevent, combat, and eliminate terrorism" was one of the main goals to bear in mind to respond to terrorist attacks which are "one of the factors that underscore the need for cooperation and the urgency of efforts to eradicate [it]." The Organization of African Unity (OAU) also proclaimed in the 2004 Protocol to the Convention on the Prevention and Combating of Terrorism of 1999 "the need to coordinate and harmonize continental efforts in the prevention and combating of terrorism in all its aspects." These are just a few examples of how different regions have recognized the need to work together to fight against the terrorist threat

11 SC Report A/59/565 (2004), 2 December 2004 
and have acknowledged the importance of adopting international instruments to cooperate between them to this end.

But the European Union has been the organization which has been more active responding to the terrorist threat. It has developed various instruments such as the EU Counter-Terrorism Strategy of 2005 or the Council Framework Decision of 13 June 2002 on Combating Terrorism (2002/475/JHA). The first, for instance, is a non-binding document, while the latter includes a series of obligations which compel states to adopt national measures to make sure that all states within the European Union had a definition of terrorism and typified all related acts.

However, the ASEAN has adopted a completely different approach. While it has also developed norms in the field such as the Declaration on Joint Action to Counter Terrorism of 2005, which called all states to improve regional cooperation in response to the 9/11 attacks, it has also passed other instruments such as the 2007 ASEAN Convention on Counter Terrorism. The document contains wide and general provisions on the fight against terrorism, but it is precise in emphasizing the importance of national laws in terrorist-related matters. This organization has shown a preference to resolve those problems connected to terrorism at the national level as they consider all security matters an essentially domestic problem. National sovereignty in security affairs, whether they affect the international community or not, is still clearly separated from the adoption of measures in the international arena. This obviously hinders regional cooperation since all states rely on different national provisions in relation to terrorism and thus follow very different interpretations and strategies. Some take more militaristic approaches, while others rely on criminal law and criminal courts. Their approximation is much more aimed at keeping security affairs through a geopolitical vision.

As the Secretary General stated once "Whatever perceptions may have prevailed when the Westphalian system first gave rise to the notion of State sovereignty, today it clearly carries with it the obligation of a State to protect the welfare of its own peoples and meet its obligations to the wider international community". ${ }^{12}$ The fact that different regions deal with security issues such as terrorism in very different ways, gets on the way of establishing any potential harmonization process and complicates finding common solutions to global problems, since some actors keep on relying to their own mechanisms and prioritizing their national security interests over multilateral cooperation. And when it comes to responding to global issues and global threats such as is that of terrorism, this hinders the potential to find an appropriate and effective solution.

\section{(E)BETWEEN COSMOPOLITISM AND WESTPHALIA}

Although after the end of the Cold War many theorists thought the biggest geopolitical problems had been resolved, and that major security threats were already overcome, recent history has shown us that reality have not turned out to be exactly this way. The intensification of the South China Sea conflict, the disputes claiming territory on the Arctic, the return to unilateralism during the Trump administration... And on top of that, terrorism. And not just the type of terrorist attacks that used to affect only specific states or regions in the world, but terrorism as a global phenomenon that has

\footnotetext{
12 Ibid.
} 
surpassed all frontiers, clearly altering international peace and security. Terrorism has grown at an exponential and uncontrollable rate, damaging both national and human security.

The complexities on the adoption of a global norm on terrorism can serve as an example to explain the tensions between Cosmopolitism and Westphalia. It is not exactly as if Cosmopolitism had been spread throughout the globe without any interferences, but the management of power based on geopolitics has remained. One may wonder whether we are returning to a Westphalian system or whether we ever left it behind. Whatever the case, the truth is that we are facing a tension between the two models, and we are left wondering which will turn out to be the predominant one.

However, in the case of security it may be easier to answer. Although terrorism has been recognized as one of the main threats to international peace and security, and although many international actors have thought it necessary to cooperate and to even work on the development of an international norm which defines terrorism as an international crime, the fact is that many keep on following their own national approaches, and we are still quite far from achieving agreement on such a norm. Many support the idea that terrorism can only be responded through cooperation, but in the field of security, states still prefer to address these issues according to their national interests and through their own national security strategies. Sovereignty remains over anything else.

What is more, because of this growing security threats, states are no longer the only relevant actors providing security. Private companies have gained a much stronger position in the market in the past decades, and it is more and more common for states to rely on enterprises to provide security in their name. Globalization has contributed to their expansion as many security threats have an international impact, and this is the case of terrorism too. The privatization of terrorism is an example of these manifestations of globalization. ${ }^{13}$ And an important aspect of the incorporation of their services and their growing reliance by states is that they also want to have a say when norms are being debated. Any laws and policies related to the protection of the territory and of the citizens concern them too, so they lobby to be an important part of the law-making negotiation process. This may also be another reason why it is becoming so hard to agree to an international norm on terrorism.

Some states are still persisting in their effort to construct an instrument of hard law in the form of a treaty to establish the crime of terrorism. Others have started defending that there may be already certain practice that may lead to a customary norm, although they acknowledge that this has not crystallized yet. And some do not want to hear about either way at all.

The creation of a customary norm is long and complex. To culminate it, it must be proven that a particular behaviour is largely accepted as a custom by the international community, which is usually done through repetitive practice over time. When it becomes widely accepted and obeyed, it is because time and practice have made it obvious that it is a custom to observe it. Nevertheless, in the case of terrorism, most of the practice has taken place in response to 9/11, which is not enough time to show that there is this needed generalization. Some may say we are in the process of creating it, as states have developed laws and policies at the national level to respond to the terrorist threat and international cooperation has been strengthened, but we are still far from talking about a customary norm. What seems to be clear though is that all states share the need to protect from terrorism and to

13 S. Adejumobi, 'A view from Africa', in A. Bailes and I, Frommelt (eds), Busines and Security. Public-private sector relationships in a new security environment (Stockholm International Peace Research Institute Yearbook, Stockholm, 2004), at 242. 
condemn this phenomenon in their national legal frameworks, but a conscious of obligatory nature has not flourished yet.

Nevertheless, some have persisted in the need to create an international treaty, precisely because they recognise that the creation of a customary norm is too slow, and we are still far from reaching the peak. Furthermore, terrorism is sufficiently grave as to react to it immediately, something that could not be done with a customary norm because of its slow and complex process of creation. That is why they believe that a Comprehensive Convention on International Terrorism could be the response to such security threats, as it can have immediate effects.

This hypothetical Convention is still a project which has not culminated in a definitive text. The initiative started with Resolution 54/110 of December 9, 1999, in which the General Assembly started considering the adoption of a norm defining the crime of terrorism. But it was not until the representation of the Indian government distributed an informal draft to the Special Committee on Terrorism that states started negotiating a normative text. The goal of this Convention would be to complement the already existing normative framework on terrorism with the typification of the crimes of terrorism; the suppression of laws establishing exceptions related to political, philosophical, ideological, racial, ethnic, religious or other similar grounds; the adoption of preventive measures to refrain potential attacks from states; and call for greater international cooperation so that all police and judicial forces can effectively combat terrorism. This would then become the general framework in relation to terrorism, which other laws and regulations would complement with more specific and limited content.

Even though we are still far today from establishing an international treaty containing the definition of terrorism, a decisive will by some to create it remains strong. Its final adoption could be seen as the superposition of the Cosmopolitist model over the Westphalian one, but if such a norm never exists it could be seen as evidence that the Westphalian way of dealing with power politics is still the only predominant model when dealing with the security sector.

However, the fact that we are still discussing whether one is more predominant over the other shows that Cosmopolitism is still a strong force to consider in today's international order, even in the area of security. Australia, Brazil, India, Indonesia, Mexico, South Korea, and Turkey are emerging democracies which play an important role in the international system and, as John Ikenberr says, they pressure towards multilateral cooperation and, along with the countries in the European Union and the United States, they are the ones to defend democracy and push towards a more liberal order ${ }^{14}$. In fact, India has been one of the most pressing states to defend the need for a Comprehensive Convention on International Terrorism, repeatedly calling states to sit at the table and negotiate during different conferences and summits. Its Prime Minister Narendra Modi has described terrorism as the "biggest problem facing the world today." 15 The BRICS have actually even established their own

14 J. G. Ikenberr 'The illusion of geopolitics: The enduring power of the liberal order', 93(3) Foreign Affairs (2014) $80-91$, at 81 .

15 The Wire, 'For the First Time, BRICS Releases Policy Document on Counter-Terrorism' (2020) November 18, 2020. Available here, accessed on July 15, 2021. 
Counter-Terrorism Working Group (CTWG), which started meeting in 2016. The work to achieve an agreement on this norm is nonetheless an uphill effort.

\section{(F)CONCLUSION}

What the persistent push for establishing a Comprehensive Convention on International Terrorism and the lack of agreement on it shows us is this continuous conflict between the Cosmopolitism and the Westphalian-model. We have seen the UN Security Council declare terrorism as one of the biggest threats to international peace and security and compelling states to criminalize terrorism as a crime under their national laws. We have seen states designing other laws and policies to address this security threat, and we have witness greater levels of cooperation between international actors to protect from the terrorist attacks. But states are still unwilling to bind themselves by certain international obligations, including the acceptance of a definition of terrorism and the approval of the Comprehensive Convention on International Terrorism. We see the need to combat a common grave security threat, yet we are unable to agree on its basis, which is its definition. Maybe the most significant conclusion of this process is precisely the lack of a specific outcome. The incapacity to create an international norm on terrorism is an absence which speaks by itself.

Thence the inclination for creating a norm on terrorism is not sufficient for achieving one, since the universality that is needed to generate an international norm is not met. The combination of national interests and what each state wants to include and exclude from a global definition of the crime makes it impossible to reach a common ground on what an act of terrorism can or cannot be. And by not committing themselves to a definition, they continue keeping a much greater degree of discretion and wider sovereignty on the way they manage all those issues related to terrorism and thus to national security. We may have been unable to create a norm defining international terrorism and we may still not see it in the short time, but we had never been so close to culminating the process.

We may even affirm that depending on the region of the world that we are looking at there is a most Cosmopolitist or Westphalian system. While it seemed that during the past decades, we had advanced towards the consolidation of Cosmopolitism and the maintenance of liberal order, we have seen some actors being more resistant, and how in some sectors such as those affecting security and national sovereignty the implementation of such a model has not been so successful. In some regions, and in some states, we see a tendency towards dealing with defence through the classical version of state sovereignty. These are the ones who are interested in keeping a conservative vision of power and sovereignty. With a phenomenon like terrorism, many states have taken advantage of the importance of such a threat to reinforce their national defence mechanisms and prioritize their domestic interests, something which can be seen as a return to those behaviours based on geopolitical conceptions. For them, international cooperation has been pushed into the background.

The lack of agreement on a global definition of terrorism and the incessant tenacity by some to create it is useful to show the existing tensions between Cosmopolitism and Westphalia. The advancement of the first so that the international legal framework is reinforced and further developed to share common interests and protect from common values is curbed by the latter, which imposes clear limits to the adoption of norms which undermine the national interests and their own specific goals. The development of an international norm on terrorism, strongly linked to defence and thus 
the sovereignty of the state, is the perfect case to show this clash between the two models and exemplifies the complex process of adopting international norms today.

Even if it may be usually hard to find common agreement on a global norm because of the multiplicity of interests, in the field of security this is even more complex. From the one hand, because of the national interests, goals, and values of each state. From the other, because security is intrinsically linked to national sovereignty, a sphere in which it is extremely strenuous to get states to give up part of their power. And on top of that, defence strategies may be completely opposite from one state to another and may show significant differences between those relying on geopolitical strategies and those who do not. The consequence is that even though there is a clear need to protect from such a dreadful threat, this seems not to be enough to agree on a definition of the crime. And it is precisely this lack of agreement and the absence of the norm which can help further understand this conflict between the dynamics of Cosmopolitism and Westphalia today. 